\title{
Analysis of land use and climate change impacts by comparing river flow records for headwaters and lowland reaches
}

Nasim Fazel ${ }^{*}$, Ali Torabi Haghighi ${ }^{1}$ and Bjørn Kløve ${ }^{2}$

Water Resources and Environmental Engineering Research Group,

University of Oulu, Oulu, Finland

\footnotetext{
${ }^{1}$ Ali.TorabiHaghighi@oulu.fi

${ }^{2}$ Bjorn.klove@oulu.fi
}

*Corresponding author:

Nasim Fazel

Water Resources and Environmental Engineering Research Group

University of Oulu, Finland

Nasim.fazel@oulu.fi

+358503500801 


\begin{abstract}
The natural flow regime of rivers has been strongly altered world-wide, resulting in ecosystem degradation and lakes drying up, especially in arid and semi-arid regions. Determining whether this is due mainly to climate change or to water withdrawal for direct human use (e.g. irrigation) is difficult, particularly for saline lake basins where hydrology data are scarce. In this study, we developed an approach for assessing climate and land use change impacts based on river flow records for headwater and lowland reaches of rivers, using the case of Lake Urmia basin, in north-westen Iran. Flow regimes at upstream and downstream stations were studied before and after major dam construction and irrigation projects. Data from 57 stations were used to establish five different time intervals representing 10 different land use development periods (scenarios) for upstream (not impacted) and downstream (impacted) systems. An existing river impact (RI) index was used to assess changes in three main characteristics of flow (magnitude, timing and, intra-annual variablity). The results showed that irrigation was by far the main driving force for river flow regime changes in the lake basin. All stations close to the lake and on adjacent plains showed significantly higher impacts of land use change than headwaters. As headwaters are relatively unaffected by agriculture, the non-significant changes observed in headwater flow regimes indicate a minor effect of climate change on river flows in the region. The benefit of the method developed is clear interpretatation of results based on river flow records, which is useful in communicating land use and climate change information to decision makers and lake restoration planners.
\end{abstract}

Keywords: flow regime alteration, climate change and variability, agriculture, dam, impact assessment, arid.

\title{
1. Introduction
}

River flow reductions have been severe in arid and semi-arid regions mainly due to human water use and in some regions also due to climate change (Keddy, et al. 2009; Wu, et al. 2012; Bengtsson. 2010; Groves, et al. 2008; Milly, et al. 2005; Döll, et al. 2009). Flow regime alterations have led to considerable changes in closed saltwater lakes such as. Aral Sea, Lake Chad, Salton Sea, Great Salt Lake and Lake Urmia (Assessment Millennium Ecosystem. 2005; Gordon, et al. 2008; Talebi, et al. 2015; Wurtsbaugh. 2014). Saline lakes are important natural assets with considerable aesthetic, cultural, economic, recreational, scientific, conservation and ecological values (Williams, 2002), but they have been ignored by researchers, governors and, policy makers until recently. Because these lakes commonly lack easily quantifiable economic value, the hydrology of the upper river systems in the basin is rarely monitored (Moore. 2016), making human and climate impact assessments analysis difficult for these lakes. The water balance of these lakes is commonly controlled by river inflows and evaporative losses. Even small changes inflow regimes could cause significant changes in lakes' level, salinity and productivity.

The impact of climate and land use change on stream flows have been analysed through different approaches, such as trend analysis of stream flows and relevant meteorological factors (Masih, et al. 2011; Zamani, et al. 2016; Yang, et al. 2010), river flow regime alteration analysis using hydrological indicators (Chen and Weisbrod. 2016; 
Ashraf, et al. 2016; Peñas, et al. 2016) and simulations based on hydrological modelling(Jarsjö, et al. 2012; Gupta, et al. 2015; Li, et al. 2016; Shibuo, et al. 2007; Mango, et al. 2011). Hydrological modelling in arid and semi-arid regions is challenging due to the semi-arid climate characteristic of frequent convective precipitation of high spatio-temporal heterogeneity and the sparse and dynamic vegetation cover. These unique physical conditions make it difficult to define hydrological parameters at high spatial resolution. Thus statistical impact assessment becomes more convenient, cost-effective and time-efficient in these regions. Although substantial progress has been made, a comprehensive and less time-demanding framework to separate and quantify the impact of climate and human interventions on river flow regime by hydrological modelling is still lacking (Krysanova and White. 2015)

In this study, we developed a unique and simple statistics-based framework to quantify and separate the impacts of climate and land-use change on flow regimes in arid and semi-arid regions. This was done by analysing changes in headwater and lowland river data using the RI (river impact) indicator developed by (Torabi Haghighi, et al. 2014). Hydrological indicators have been widely used in many studies, mainly to assess the impact of dam construction on river flow regime alterations (Döll and Schmied. 2012). In this study, the degree of hydrological alteration in different river reaches in the Urmia basin was assessed and mapped.

\section{Material and Methods}

\subsection{Lake Urmia basin and river networks}

Lake Urmia in north-west Iran (Fig.1), once one of the largest lakes in the Middle East, is suffering from severe lake level decline. Over history the lake surface area varied naturally from $5000 \mathrm{~km}^{2}$ to $6000 \mathrm{~km}^{2}$ owing to seasonal and annual climate variability, but the current surface is only $1647 \mathrm{~km}^{2}$ (Tourian, et al. 2015; Hamzekhani, et al. 2016). The lake and its $52,000 \mathrm{~km}^{2}$ catchment are important for 6.5 million people whose main sources of income are agriculture and industry. Cropland and orchards comprise about $10 \%$ of the catchment area but consume more than $90 \%$ of all renewable water resources in the Lake Urmia basin (OWWMP, 2011). Surface water provides about $60 \%$ of agricultural water demand (OWWMP. 2011a), via reservoirs, diversion dams, canals, and pumps from rivers and streams. The construction of large dams along the main stream and major tributaries has significantly changed the natural flow regime of the basin's rivers.

Lake Urmia is a terminal saline lake. The mean annual precipitation in the basin is about $357 \mathrm{~mm}$, mainly falling in winter and spring. The annual potential evaporation in the area varies from $1050 \mathrm{~mm}$ in the north-east to 1550 $\mathrm{mm}$ in the south-west (OWWMP. 2011b). Runoff dominates in spring due to snowmelt from mountainous terrain providing water to the basin's 15 rivers and the lake. Two rivers in southern parts of the catchment (Zarrineh-Rud and Simineh-Rud) provide most of the lake inflow (50\%). The catchment area of the basin's rivers varies from 58 $\mathrm{km}^{2}$ (river Daryan-Chay at Drayan station) to $11,578 \mathrm{~km}^{2}$ (Zarrineh-Rud at Nezam-Abad station) and their inflow to the lake at their last gauging station varies from $0.15 \mathrm{~m}^{3} \mathrm{~s}^{-1}$ (at Khorkhoreh station on Tamar-Chay) to $57 \mathrm{~m}^{3} \mathrm{~s}^{-}$ ${ }^{1}$ (at Nezam-Abad station on Zarrineh-Rud).

More than 170 dams have been built to irrigate the central plains surrounding the lake. To maximise irrigation, increase access to water and develop agriculture in the region, river regulation was started in early 1970 with the construction of two large reservoirs, on the north-flowing rivers Zarrineh-Rud (Bukan dam, $0.605 \mathrm{~km}^{3}$ ) and Mahabad-Chay (Mahabad dam, $0.2 \mathrm{~km}^{3}$ ). The Zarrineh-Rud and Simineh-Rud, the largest rivers in the lake basin, 
are fed by water from the Zagros Mountains flowing north to the lake (Fig. 1). By late 2010, three dams were regulating about $0.64 \mathrm{~km}^{3}$ water in the southern part of the basin (OWWMP. 2011a). The Godar-Chay, BaranduzChay and Shahr-Chay are important rivers flowing from the west and south-west to the lake and regulate about $0.211 \mathrm{~km}^{3}$ water. The Aji-Chay, the largest river flowing to the lake from the east (Fig. 1), has 13 dams on its tributaries and main stream, with total regulated volume of $0.38 \mathrm{~km}^{3}$. The total dam regulation volume in the Lake Urmia basin had increased to $3.2 \mathrm{~km}^{3}$ by late 2013 (Fig. 1b).

Fig. 1. a) Lake Urmia study area and stream gauging sites, b) dam construction points, the lake basin's RI index and, lake levels in study periods 2-5 (1965-2013) and, c) Annual evaporation from three synoptic stations around the lake significant increasing trend at $95 \%$ significant level

\subsection{Flow regime change assessments}

Flow regime alteration can affect three main characteristics of monthly river flow: i) magnitude, ii) timing and iii) intra-annual variability of flow (Fig. 2). To quantify the impact of natural and anthropogenic river flow alteration and overcome the lack of daily flow data, we used the RI index methodology proposed by (Torabi Haghighi, et al. 2014) to assess the effects of a flow magnitude impact factor (MIF), a flow regime variation impact factor (VIF) and a flow timing impact factor (TIF). The hydrometric network in Lake Urmia basin consists of 110 stream gauges (OWWMP. 2011a) producing data time series of different lengths and frequent missing data. From the initial database, stations with at least eight years of records in each period shown in Fig. 1 were selected for the analysis, resulting in 57 streamflow gauging stations. These stations are spread throughout the headwaters, middle and lower reaches of the rivers in the Lake Urmia basin.

Fig. 2. A) Natural flow regime and impacts of dam construction on the flow hydrograph due to: b) the flow magnitude function (magnitude impact factor, MIF), c) the flow regime alteration function (variability impact factor, VIF) and d) the flow timing function (TIF) (based on Torabi Haghighi et al., 2014).

The RI value is calculated from MIF, TIF and VIF as:

$R I=M I F \times(T I F+V I F)$

The value varies between 1 (natural river flow) and 0 (completely changed river flow). The magnitude impact factor is calculated as:

$M I F=A F_{\text {Post }} / A F_{\text {Pre }}$

where $\mathrm{AF}_{\text {Pre }}$ is the annual flow in the pre-change period and $\mathrm{AF}_{\text {Post }}$ the annual flow in the post-change period for the specific gauge. The intra-annual flow variability factor (VIF) quantifies the variation in the hydrograph (Haghighi and Kløve. 2013):

$V I F=\frac{50-0.5 \times I_{R R}}{100}$
$I_{R R}=\frac{\left|R R I_{\text {Pre }}-R R I_{\text {Pos }}\right|}{R R I_{\text {Pre }}} \times 100$ 


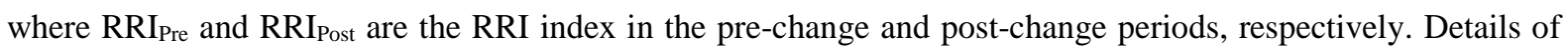
RRI calculation can be found in (Haghighi and Kløve. 2013). The flow timing impact factor (TIF) takes into account shifts in maximum, minimum and $50 \%$ of discharge cumulative density function (Torabi Haghighi, et al. 2014):

$T I F=\frac{50-0.274 \times T F}{100}$

$T F=\frac{\left|D T_{\text {Max }}\right|+\left|D T_{\text {Min }}\right|+\left|D T_{\text {Median }}\right|}{3}$

where $\mathrm{DT}_{\mathrm{Max}}, \mathrm{DT}_{\mathrm{Min}}$ and $\mathrm{DT}_{\text {Median }}$ are the time shifts in monthly maximum discharge, monthly minimum discharge and CDF50 timing value, respectively. The RI index range is defined by five different impact classes (Table 1), where a value of 0.8-1.0 represents a low impact (less than $20 \%$ alteration in flow regime characteristics), 0.6-0.8 an incipient impact, 0.4-0.6 a moderate impact, 0.2-0.4 a severe impact and 0-0.2 a drastic impact (more than 80\% alteration in river flow regime). For more information, see (Torabi Haghighi, et al. 2014).

Table 1. River impact (RI) classes, ranges and percentage alterations in river flow regime

\begin{tabular}{lll}
\hline Impact class & Range of RI & Total Impact $(\%)$ \\
\hline Drastic impact & $0 \leq \mathrm{RI}<0.2$ & $100-80$ \\
Severe impact & $0.2 \leq \mathrm{RI}<0.4$ & $80-60$ \\
Moderate impact & $0.4 \leq \mathrm{RI}<0.6$ & $60-40$ \\
Incipient impact & $0.6 \leq \mathrm{RI}<0.8$ & $40-20$ \\
Low impact & $0.8 \leq \mathrm{RI}<1$ & $<20$ \\
\hline
\end{tabular}

To analyse the impact of water resources infrastructure on river flow regime, we identified pre- and post-change periods based on modification of rivers in the study area. Monthly flow data (1949-2013) for the Iranian water year (from October to September) were divided into five intervals. Period 1 (before 1965) acted as the baseline (pre-change) period, with no significant human interventions, no dam construction and no water resources development work. Period 2 (1965-1977) encompassed the first phase of water resources development work in the lake basin, with construction of the Shahid Kazemi (1970) and Mahabad (1971) reservoirs. Period 3 (19771989) coincided with the Iran-Iraq war (1980-1988), which halted development plans throughout the country. However, total regulated volume increased by $0.015 \mathrm{~km}^{3}$ through construction of 13 small dams in Lake Urmia basin (Fig. 1b). Period 4 (1989-2001) marked the start of modern water resources exploitation, with construction of 11 dams giving a total regulated volume of $0.28 \mathrm{~km}^{3}$. The lake started drying up in this period (Fig. 1b). Period 5 (2001-2013) was the main development period, despite awareness that the lake was already drying up. Total regulated volume increased by $2.1 \mathrm{~km}^{3}$, to $3.2 \mathrm{~km}$, with construction of 25 dams, which is twice the total regulated volume before 2001. We assessed flow regime alterations considering all important environmental changes and their individual effects in the following periods. The analysis was performed by developing 10 temporal scenarios using pair-wise combinations of periods 1-5 (Table 2): SC1-2 = periods 1 and 1; SC1-3 = periods 1 and 3; SC1-4 $=$ periods 1 and 4; SC1-5 = periods 1 and 5; SC2-3 = periods 2 and 3; SC2-4 = periods 2 and 4; SC2-5 = periods 2 and 5; SC3-4 = periods 3 and 4; SC3-5 = periods 3 and 5; and SC4-5 = periods 4 and 5. 
Table 2. Pre-change and post-change periods in each scenario (SC) pairing of periods 1-5

\begin{tabular}{lllllllllll}
\hline Scenario & SC1-2 & SC1-3 & SC1-4 & SC1-5 & SC2-3 & SC2-4 & SC2-5 & SC3-4 & SC3-5 & SC4-5 \\
\hline $\begin{array}{l}\text { Pre- } \\
\text { change } \\
\text { period }\end{array}$ & $\begin{array}{l}\text { Before } \\
1965\end{array}$ & $\begin{array}{l}\text { Before } \\
1965\end{array}$ & $\begin{array}{l}\text { Before } \\
1965\end{array}$ & $\begin{array}{l}\text { Before } \\
1965\end{array}$ & $\begin{array}{l}1965- \\
1977\end{array}$ & $\begin{array}{l}1965- \\
1977\end{array}$ & $\begin{array}{l}1965- \\
1977\end{array}$ & $\begin{array}{l}1977- \\
1989\end{array}$ & $\begin{array}{l}1977- \\
1989\end{array}$ & $\begin{array}{l}1989- \\
2001\end{array}$ \\
$\begin{array}{l}\text { Post- } \\
\text { change } \\
\text { period }\end{array}$ & $1965-$ & $1977-$ & $1989-$ & $2001-$ & $1977-$ & $1989-$ & $2001-$ & $1989-$ & $2001-$ & $2001-$ \\
\hline
\end{tabular}

For lake water balance assessment, a simple water balance model was assumed as:

$V_{i+1}=V_{i}+\left(R_{i}+P_{i}+G_{i}-E_{i}\right)$

where $R_{i}$ is surface water inflow to the lake, $P_{i}$ is precipitation on the lake, $G_{i}$ is groundwater inflow to the lake and, $E_{i}$ is evaporation from the lake surface in current month. $V_{i}$ and $V_{i+1}$ are lake volume in first day of current and next months. Annual groundwater inflow to the lake is assessed to be 220 MCM (OWWMP. 2011c) which is legible compared to other fluxes (we have assumed $\mathrm{G}_{\mathrm{i}}$ equal to zero). Average evaporation from the lake surface was estimated based on monthly pan evaporation at stations adjacent to Lake Urmia and Thiessen method. The observed monthly evaporations were corrected by pan coefficient and salt coefficient (JICA. 2016). The precipitation over the lake surface was estimated by Thiessen method and observed precipitation from stations near the lake. The water balance model performance was evaluated by Nash-Sutcliffe model efficiency coefficient (obtained value 0.73 ). To analyse the impact of water consumption on the lake volume, we generated four scenarios: Scenario 1: inflow to the lake for years 1966-2010 continues as it was in period 1 (before 1966), Scenario 2: inflow to the lake for 1977-2010 is as in period 2 (1966-1977), Scenario 3: inflow to the lake for 19892010 is equal to 1978-1988 inflows, and Scenario 4: inflow to the lake for 2001-2010 is as in period 4 (19892001).

\section{Results}

\subsection{Flow regime alteration in lower reaches and headwater of the rivers}

During the observation period (1965-2013), the main changes in the lake water balance components is observed for average inflow as it changes from $2362 \mathrm{MCM}$ (before agricultural land development) to 1592 (after development in 1978-2013). The evaporation directly from the lake remains nearly unchanged despite the reduction in area due to more pan evaporation with time. The average precipitation changes slightly from $300 \mathrm{~mm}$ before 1978 to 275 after in period 1978-2013. The results of the lake water balance simulation for the four generated scenarios suggest that the water consumption in the lake basin has had significant impact on the lake volume (Fig. 3).

Fig.3 Lake's estimated volume for different inflow scenarios 1-4.

The analyses showed a considerable reduction in mean annual discharge in the large lowland rivers flowing into Lake Urmia, whereas the discharge in smaller headwater streams changed only slightly (Fig. 4, Fig. 5b-g, Table 
3). As the lowland river reaches are affected by dams and irrigation and the headwater streams are rather unaffected, it can be deduced that the observed change in discharge in the former is caused by expansion of agricultural activities, and not by climate.

The RI index analysis showed that the flow at gauging stations located close to the lake (in lower reaches of the rivers) had undergone moderate to severe changes, especially in period 5 (2001-2013) (Fig. 4a). However, regional differences were also found. In the eastern part of the catchment, the most severe changes occurred in period 4 (1989-2001). The river Shahr-Chay, flowing from the west to the lake, suffered the most significant change, with about $82 \%$ alteration in flow ( $\mathrm{RI}=0.20$ at Keshtiban station). The river flow in the two most important rivers feeding Lake Urmia, the Zarrineh-Rud and Simineh-Rud in the south, fell into the category of severely impacted in the SC2-5 and SC4-5 comparisons, with an estimated RI factor of 0.32 (Fig. 4). The smallest change in flow regime of the major rivers was observed for the Baranduz-Chay in the west of the region ( $\mathrm{RI}=0.46$ at Babarud station) (Table 3).

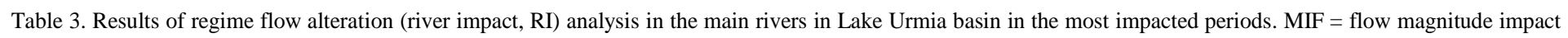
factor, $\mathrm{VIF}=$ flow variation impact factor and $\mathrm{TIF}=$ flow timing impact factor

\begin{tabular}{|c|c|c|c|c|c|c|c|c|c|c|c|c|}
\hline \multirow{3}{*}{ River } & \multirow{3}{*}{$\begin{array}{l}\text { Contribut } \\
\text { ion to } \\
\text { lake } \\
\text { inflow } \\
(\%) \\
\end{array}$} & \multirow{3}{*}{$\begin{array}{l}\text { Gauging } \\
\text { station } \\
\text { code }\end{array}$} & \multirow{2}{*}{\multicolumn{8}{|c|}{ RI analysis }} & \multirow{3}{*}{$\begin{array}{l}\text { Total } \\
\text { regulated } \\
\text { volume, } \\
\mathrm{km}^{3}\end{array}$} & \multirow{3}{*}{$\begin{array}{l}\text { Irrigation } \\
\text { network fed } \\
\text { by dam, } \mathrm{km}^{2}\end{array}$} \\
\hline & & & & & & & & & & & & \\
\hline & & & $\begin{array}{l}\text { Pre-change } \\
\text { period }\end{array}$ & $\begin{array}{l}\text { Post-change } \\
\text { period }\end{array}$ & RI & MIF & TIF & VIF & RI class & Scenario & & \\
\hline $\begin{array}{l}\text { Zarrineh- } \\
\text { Rud }\end{array}$ & 38 & $56-917$ & $1965-1977$ & 2001-2013 & 0.32 & 0.42 & 0.88 & 0.66 & Severe & $\mathrm{SC} 2-5$ & 0.556 & 86560 \\
\hline $\begin{array}{l}\text { Simineh- } \\
\text { Rud }\end{array}$ & 14 & 33-039 & 1989-2001 & 2001-2013 & 0.32 & 0.34 & 0.93 & 0.94 & Severe & SC4-5 & 0.261 & 18046 \\
\hline Aji-Chay & 9 & $31-015$ & $1965-1977$ & $2001-2013$ & 0.32 & 0.35 & 0.92 & 0.93 & Severe & $\mathrm{SC} 2-5$ & 0.38 & - \\
\hline Godar-Chay & 9 & $34-021$ & 1977-1989 & 2001-2013 & 0.39 & 0.43 & 0.99 & 0.82 & Severe & SC3-5 & 0.1 & 13961 \\
\hline $\begin{array}{l}\text { Baranduz- } \\
\text { Chay }\end{array}$ & 7 & $35-007$ & $1965-1977$ & 2001-2013 & 0.47 & 0.56 & 0.94 & 0.74 & Moderate & $\mathrm{SC} 2-5$ & - & 34300 \\
\hline Mahabad & 5 & 34-009 & 1989-2001 & 2001-2013 & 0.26 & 0.33 & 0.66 & 0.97 & Severe & SC4-5 & 0.2 & 11800 \\
\hline Shahr-Chay & 3 & $35-013$ & 1965-1977 & 2001-2013 & 0.18 & 0.29 & 0.75 & 0.50 & Drastic & $\mathrm{SC} 2-5$ & 0.199 & 11970 \\
\hline
\end{tabular}

Fig. 4. Hydrographs before and after dam construction and the river impact (RI) index: a) results of RI analysis for downstream stations in all scenarios (MIF = flow magnitude impact factor, VIF = flow variation impact factor and TIF = flow timing impact factor). Grey: SC1-2, Light green: SC1-3, Light blue: SC1-4, Orange: SC1-5, Dark red: SC2-3, Pink: SC2-4, Peach: SC2-5, Dark blue: SC3-4, Dark green: SC3-5, Black: SC4-5; and RI value determined for the river b) Zarrineh-Rud, c) Simineh-Rud, d) Aji-Chay, e) Godar-Chay, f) Mahabad-Chay and g) Baranduz-Chay in scenario SC2-5 (1965-1977 as the pre-change period and 2001-2013 as the post-change period).

As can be seen in Fig. 5a-f, the hydrographs of headwater streams did not change significantly over time and in most cases the post- and pre-impact period hydrographs were identical, except for a few stations with agriculture in their catchment. Consequently, most of the headwater streams were in the low or incipient impact classes (Fig. $5 \mathrm{~g}$ ), with an RI value ranging from $0.4-0.99$, and only about $20 \%$ were classified as being in the moderate impact 
class (Fig. 4g). In fact, the headwater streams of most of the major rivers were in the low or incipient impact class even in the last period (2001-2013) (Fig. 5). The greatest change in headwater flows was observed at Mirabad station in the river Shahr-Chay, with $\mathrm{RI}=0.42$. These results suggest that factors other than climate change were responsible for the changes in stream flow observed for the lower areas of the basin.

Fig. 5. Hydrographs before and after dam construction and the river impact (RI) index: a) results of RI analysis for headwater stations in all scenarios $(\mathrm{MIF}=$ flow magnitude impact factor, VIF $=$ flow variation impact factor and TIF = flow timing impact factor). Grey: SC1-2, Light green: SC1-3, Light blue: SC1-4, Orange: SC1-5, Dark red: SC2-3, Pink: SC2-4, Peach: SC2-5, Dark blue: SC3-4, Dark green: SC3-5, Black: SC4-5; and RI value determined for the river b) Sarugh at Safakhaneh station (33-021, headwater of Zarrineh-Rud), c) Cham-Saqez at Ghabghablu station (33-007, headwater of Zarrineh-Rud), d) Nazul-Chay at Tipik station (35-031, head water of Nazul-Chay), e) Mahabad-Chay at Kuter station (34-003, headwater of Mahabad-Chay), f) Godar-Chay at PeyQaleh station (34-011, headwater of Godar-Chay) and g) Baranduz-Chay at Hashemabad station (35-003, headwater of Baranduz-Chay) in scenarios SC2-5/SC4-5 (1965-1977 as pre-change period, 2001-2013 as postchange period/1989-2001 as pre-change period, 2001-2013 as post-change period) based on availability of data.

\subsection{Spatial and temporal changes in flow regime characteristics}

Among the three characteristics of river flow regime evaluated, flow magnitude displayed the greatest degree of alteration throughout the region (Fig. 6a). In the lower reaches of the major rivers it declined significantly, by 44\% in Baranduz-Chay and 67\% in Mahabad-Chay. In contrast, the flow magnitude decrease in headwater streams, which were not affected by water regulation and withdrawals due to dams and irrigation networks, was on average only $20 \%$. Rivers in southern lowlands adjacent to the lake showed a larger reduction in flow magnitude $(\mathrm{MIF}=0.33-0.5)$ than rivers in other parts of the basin. Rivers in the north-west of the lake basin also displayed large reductions in flow magnitude over later decades. Stream flow magnitude for the river Zula-Chay, with an average inflow of 54 million cubic metres $(\mathrm{MCM})$ to the lake, declined significantly $(\mathrm{MIF}=0.31)$ in period 5 (2001-2013) compared with period 4 (1989-2001), while the reduction in flow magnitude was just about $20 \%$ $(\mathrm{MIF}=0.8)$ at the end of period 4 in comparison with period 3 (1977-1989). The observed reductions in flow magnitude in lower reaches of the main rivers (e.g. Zarrineh-Rud and Simineh-Rud) were much larger than those in their headwaters, but little change was observed for flow timing and intra-annual variability. For example, the VIF varied insignificantly from 3\% in Mahabad-Chay to 33\% in Zarrineh-Rud. Higher values of VIF were found for the basin's mountainous edges in the west, but in general VIF was similar for the entire basin. There were only small changes in flow timing characteristics (TIF) and no general pattern was distinguished for stations in headwaters compared with lower reaches of the rivers. The only station showing moderate changes in TIF was the headwater stream of the river Zula-Chay in the north-west of the lake basin, which showed a 124-day shift in maximum flow timing.

Fig. 6. Spatial pattern of changes in flow regime characteristics in Lake Urmia basin: a) Flow magnitude impact factor (MIF), b) intra-annual variability impact factor (VIF) and c) flow timing impact factor (TIF). 
Temporal flow regime assessments suggest that periods 4 (1989-2001) and 5 (2001-2013) were the most critical periods for the lake basin (SC3-5 and SC4-5 in Fig. 7). The most significant changes occurred in scenarios in which the flow regime in different periods was compared with that in period 5 (2001-2013). The greatest changes in both lowland and headwater reaches were observed in SC2-5, which covered the cumulative impacts of changes from period 2 (1965-1977) to period 5 at 20 available stations (Fig. 7). Moreover, flow regime impacts showed an increase to higher impact classes in later decades. Comparison of changes between period 2 and period 3 (19771989) revealed that most of the rivers were in the low to incipient impact classes, whereas the changes from period 3 to period 5 were mostly in the severe impact class.

Fig. 7. Temporal flow regime alterations in sub-basins of the Lake Urmia basin in the 10 different time comparison scenarios studied (see Table 2).

\section{Discussion}

Large endorheic saline lakes are unique hydrological systems that provide critical habitats for migrating shorebirds and waterbirds throughout the world. Salinity, and hence productivity, in endorheic saline lakes are controlled by the hydrology of the lake basin and geochemical processes within the lake (Moore, 2016). The balance between inflow and evaporation determines the volume of the lake (Haghighi, et al. 2016; Haghighi and Kløve. 2015). Inflow can change in response to natural climate variability, human-induced climate change and diversion of upstream water sources. Both climate and direct land use change are threatening large saline lakes world-wide (Moore. 2016; Jellison, et al. 009). This study showed the main impact is being caused by irrigated agriculture, facilitated by dam construction and irrigation network installation. The same causes has been reported for desiccation of Great Salt Lake (Wurtsbaugh. 2014) and the Aral Sea (Williams. 2002). Given the reported changes in climate in the region of decreased precipitation and increased temperature (Delju, et al. 2013; Fathian, et al. 2014; Arkian, et al. 2016), we initially expected some changes in streamflow in the headwaters, but no significant changes were noted.

Saline lakes have been largely ignored until recently, perhaps partly because of the lack of an easily quantifiable economic value (Moore. 2016; Williams. 2002). Their basin's hydrology is rarely monitored, making it difficult to determine water balance and attribute lake drying to water use or climate. The available data are usually in coarse resolution on both spatial and temporal scales. Such lack of data and tools for analysis can even lead to conflicting assumptions (Peñas, et al. 2016). Flow regime alliteration in their basins due to climate and human activities could be reflected in changed size and salinity since saline lakes are sensitive to even small changes in inflow. River flow regime alteration analysis can help to understand dominant drivers in lakes' hydrology. In this study, we analysed flow regime alterations in the Lake Urmia basin as a case study located in north-western Iran in the period 1949 to 2013 . Water in this basin is highly regulated by a high number of dams (Fig. 1b). Reservoirs and irrigation networks have changed the river regime, to compensate for the mismatch between water availability and high demand for irrigation water during the dry season. Agriculture is now using more than $90 \%$ of all available water resources, resulting in the lake drying up. This pattern is similar to that in most regulated river basins throughout the world (Torabi Haghighi, et al. 2014; López-Moreno, et al. 2004). Estimating the proportion of the streamflow reduction due to climate change is difficult, because climate interacts with land cover and land use and with population needs, and these have also changed over time in the lake basin. The hydrological regime 
in the source region of all main rivers appeared to be dominated by natural forces, whereas human interference, including dams, reservoirs, water and soil conservation measures, water withdrawal and diversion, was identified as the primary driving force for hydrological processes in the middle and lower reaches of the rivers in the basin. The analysis of headwater and lowland data clearly demonstrated these changes in an easily understandable way that can be used in communication with decision makers.

There are several methods that use river flow-based hydrological indices, e.g. the indicator of hydrological alteration (IHA) is considered one of the most effective approaches for assessing hydrological changes. These methods usually employ daily runoff data which have limited applicability with the scarcity of hydrological data in many arid and semi-arid saline lakes. Moreover, in the Lake Urmia basin the resolution of available data is not sufficient for daily flow analysis. Such assessments on short timescales are often important for e.g. ecological or biological studies, whereas analyses on larger timescales are useful for macro-level water resources management. Most arid regions lack proper management measures that consider such hydrological changes. To quantify the impact of natural and anthropogenic river flow alteration and handle the lack of daily flow data, we used the monthly-based RI index developed by (Torabi Haghighi, et al. 2014). The RI method overcomes the lack of fine resolution data in a basin and allows the impact of natural and anthropogenic flow alteration in scarce-data regions to be quantified.

Comparison of changes estimated by the RI method in regulated and non-regulated sub-basins of the Lake Urmia catchment showed differences between stations at headwaters and lower reaches of the rivers. There was no significant alteration in the flow regime of headwater streams, but most of the downstream stations were in the severe or drastic impact classes. The small flow reduction noted for some headwater stations (Fig. 5c-e) may be attributable to the documented decrease in rainfall in the region from 1960-2010 (Delju, et al. 2013; Fathian, et al. 2014; Arkian, et al. 2016). However, the differences between magnitude of changes in headwater and downstream discharge are clearly due to agriculture and irrigation. For example, the low spatial variabilityty in precipitation (Fazel, et al. 2017) cannot explain the large variation in flow between rivers reaches, which suggests that lower reaches are affected by factors other than climate. The pattern observed in the lower reaches of the rivers are clearly related to increased irrigation demand, flow regulation and water impoundment. On examining changes in the three main flow characteristics (magnitude, inter-annual variability and timing) in rivers in the basin, we found that flow magnitude (MIF) showed the largest range of variability. We also detected a significant alteration in the flow regime of lower reaches of the river Godar-Chay, which has an off-stream dam (built in 2000 ) and a reservoir for agricultural use (built in 1988) in operation in its upstream tributaries. The flow regime in its lower reaches had been altered by about $62 \%$ and flow magnitude had decreased by $57 \%$, while in headwater streams the estimated alteration was only about $17 \%$. Another example in the case of Lake Urmia basin is the river Simineh-Rud, in which flow magnitude decreased by $15 \%$ in SC4-5, while flow variability (VIF) and timing (TIF) changed by just $2 \%$. Although dam construction in the Simineh-Rud only started in period 5, changes in river flow regime had already been caused by irrigation, drainage and land reclamation in late period 4 and early period 5, which led to an increase in agricultural land area of 18,046 ha. Flow magnitude is mainly affected by flow regulation, water storage and direct surface water withdrawals, while climate change and climate variation are most likely to affect flow timing and flow variability (Torabi, 2014). 
Our results indicate that human interventions, in particular water abstraction for irrigation, was the main driver of flow regime alteration in lower reaches of the rivers that flow into Lake Urmia. With agriculture being responsible for more than $90 \%$ of the annual water use in the lake basin (OWWMP. 2011a), intensive water withdrawals govern pattern of stream flow alterations in the basin. The lake water balance simulation under generated scenarios also confirms that water abstraction and agricultural development has led to significant reductions in the lake volume. As expected, the implementation of the non-development scenarios resulted in an increase in the lake volume. These findings are in line with those reported by Hassanzadeh, et al. (2012) and Jalili, et al. (2016) on investigation of impact of climate and human activities on the lake level and fluctuations. The former has been conducted by means of a hydrological model developed for the lake basin considering impact of dams where the later analyses the lake's responses to the observed climate variabilities. In both studies, the reduction in lake level could not be explained by climate change or variability. Dams and human interventions were highlighted as the most influential factors in the lake desiccation.

Our framework overcomes the need for a sufficient hydrologic model to address the complex water allocation systems and the need for more detailed data in some cases daily data. The proposed approach is particularly applicable in saline lakes basins commonly found in arid and semi-arid regions. The results obtained are comparable with other extensive studies in similar climate and river basins using complex hydrological modelling (Hassanzadeh, et al. 2012; Guo, et al. 2016; Zhang, et al. 2016; Zhan, et al. 2013), flow regime alteration index (IHA) analysis (Stefanidis, et al. 2016; Wang, et al. 2014; Wang, et al. 2016) or direct analysis of streamflow (Vicente-Serrano, et al. 2017; Gao, et al. 2012; Batalla, et al. 2004). The outcome of previous studies is a disassociation between change in climate and streamflow. Climate has played a minor part in changes in water bodies in the regions of interest. Worldwide in arid and semi-arid regions headwaters are less affected by changes in water regulation and land use changes. Therefor comparison of the streamflow regime in headwaters with lowlands reaches can explain the impact of human activities and water abstractions.

The proposed RI methodology provides an easily understandable framework to assess impact of climate and human activities on river flow regime alterations in arid and semi-arid regions with irrigated agriculture. The methodology captures the impact of recent droughts (1999-2001) in Lake Urmia basin, (Saghafian and Hamzekhani. 2015) as in late period 4 and early period 5 where we observed reduction in headwater flows in comparison to earlier periods. With the introduced methodology, we identified the severity of reductions in headwater flows in incipient impact class while in most of the downstream stations we observed severe to moderate impacts. Although the difference between observed changes in headwaters and downstream flows can be explained, there are some drawbacks and uncertainties that still need to be addressed with the RI method, particularly in relation to the availability of data in pre-change and post-change periods. In the specific case of Lake Urmia basin, there was a lack of data not only on temporal scale, but also on spatial scale, e.g. the distribution of streamflow gauging stations was not sufficient to allow the precise impact of land use in the region to be evaluated. The current lack of gauges immediately downstream of the dams and the large irrigation canal networks could lead to underestimation of the effect of water impoundment and withdrawal. For example, there is no gauging station downstream of the Alavian dam on the river Sufi-Chay. As regards temporal scale, the available data for different stations represented different lengths of recording periods, in some cases with long gaps in 
between (e.g. Keshtiban station at the mouth of the river Shahr-Chay) which made it difficult to evaluate the effect before and after water resource development projects.

Access to adequate and reliable data is a fundamental requirement for any type of assessment in water resources management. Lack of sufficient data in the Lake Urmia basin appears to be one of the main obstacles to understanding lake water balance and devising appropriate solutions for the current crisis. In order to better address the flow regime changes and assess the impact of water regulation, particularly in rarely monitored saline lake basins, it could be beneficial to modify the streamflow monitoring networks especially at the mouth of major rivers (inlet points to the lake), upstream and downstream of withdrawal sites. Moreover, the current water management schemes in saline lake basins in arid and semi-arid regions with large-scale withdrawals for agriculture are drastically acceleration the lake drying process (Moore. 2016). Our findings showed that human interventions have the greatest impact on rivers and sub-basins and indicated that sub-basins should be prioritised when initiating future river management and lake restoration plans.

\section{Conclusions}

This study showed that the main consequence of increasing river impoundment in the Lake Urmia basin is greater flow regime alteration in lower reaches of the basin's rivers compared with their headwaters. This is due to rapid land use change towards more irrigated agriculture since 1965. Changes in river flow in the period 1965-2013 cannot be explained by climate change, the effects of which occur much more slowly than those of land use change in the region. A significant effect of water withdrawal on river flow regime alteration and lake inflow was observed for recent decades. However, the percentage of the streamflow reduction due to climate change in the study period was more difficult to assess, as the effects were masked by considerable land cover and land use changes in the lake basin. Some minor changes were observed in the unregulated headwaters of rivers between 1949 and 2013 , and these could have been due to natural climate variability or anthropogenic climate change.

The reduction in river flow magnitude increased from headwaters to downstream reaches for all rivers. Flow timing and variability throughout the region were not significantly altered, however, indicating that changes in the flow regime are controlled primarily by amount of withdrawals and impoundments. Plains adjacent to Lake Urmia displayed the largest flow reductions over time, as a consequence of upstream impoundments and withdrawals. Regime flow alteration in the eastern part of the lake basin was mostly caused by dams and diversions in tributaries, while in the southern part of basin installation of canal and irrigation networks was the dominant cause. In a temporal perspective, we observed considerable changes from period 3 (1977-1989) to period 4 (19892001) in the eastern part of the basin, while in southern, western and northern parts the changes became significant from period 4 to period 5 (2011-2013). This implies that water resources developments increased more recently in the south, west and north, while in the east the pace of development slowed down.

Saline lake inflow world-wide is controlled by climate and direct human factors and it is critical to preserve these lakes using all available information and methods. The approach used here could be applied to all such lakes, to evaluate the impact of upstream water use and determine critical areas. This in turn could lead to development of more sustainable restoration and preservation plans. 


\section{References}

Arkian, F., Nicholson, S. E., Ziaie, B., 2016. Meteorological factors affecting the sudden decline in Lake Urmia's water level. Theoretical and Applied Climatology. 1-11.

Ashraf, F. B., Haghighi, A. T., Marttila, H., Kløve, B., 2016. Assessing impacts of climate change and river regulation on flow regimes in cold climate: A study of a pristine and a regulated river in the sub-arctic setting of Northern Europe. Journal of Hydrology. 542, 410-422.

Assessment Millennium Ecosystem (Ed.), 2005. Ecosystems and human well-being: wetlands and water synthesis. World resources institute, Washington, DC.

Batalla, R. J., Gomez, C. M., Kondolf, G. M., 2004. Reservoir-induced hydrological changes in the Ebro River basin (NE Spain). Journal of Hydrology. 290, 117-136.

Bengtsson, L., 2010. The global atmospheric water cycle. Environmental Research Letters. 5, 025202.

Chen, A., Weisbrod, N., 2016. Assessment of anthropogenic impact on the environmental flows of semi-arid watersheds: the case study of the lower Jordan River, in: Anonymous Integrated Water Resources Management: Concept, Research and Implementation. Springer, pp. 59-83.

Delju, A., Ceylan, A., Piguet, E., Rebetez, M., 2013. Observed climate variability and change in Urmia Lake Basin, Iran. Theoretical and Applied Climatology. 111, 285-296.

Döll, P., Fiedler, K., Zhang, J., 2009. Global-scale analysis of river flow alterations due to water withdrawals and reservoirs. Hydrology and Earth System Sciences. 13, 2413-2432.

Döll, P. and Schmied, H. M., 2012. How is the impact of climate change on river flow regimes related to the impact on mean annual runoff? A global-scale analysis. Environmental Research Letters. 7, 014037.

Fathian, F., Morid, S., Kahya, E., 2014. Identification of trends in hydrological and climatic variables in Urmia Lake basin, Iran. Theoretical and Applied Climatology. 119, 1-22.

Fazel, N., Berndtsson, R., Uvo, C. B., Madani, K., Kløve, B., 2017. Regionalization of precipitation characteristics in Iran's Lake Urmia basin. Theoretical and Applied Climatology. 1-11.

Gao, B., Yang, D., Zhao, T., Yang, H., 2012. Changes in the eco-flow metrics of the Upper Yangtze River from 1961 to 2008. Journal of Hydrology. 448, 30-38.

Gordon, L. J., Peterson, G. D., Bennett, E. M., 2008. Agricultural modifications of hydrological flows create ecological surprises. Trends in Ecology \& Evolution. 23, 211-219.

Groves, D. G., Yates, D., Tebaldi, C., 2008. Developing and applying uncertain global climate change projections for regional water management planning. Water Resources Research. 44.

Guo, J., Su, X., Singh, V. P., Jin, J., 2016. Impacts of climate and land use/cover change on streamflow using SWAT and a separation method for the Xiying River Basin in Northwestern China. Water. 8, 192.

Gupta, S. C., Kessler, A. C., Brown, M. K., Zvomuya, F., 2015. Climate and agricultural land use change impacts on streamflow in the upper midwestern United States. Water Resources Research. 51, 5301-5317.

Haghighi, A. T. and Kløve, B., 2015. A sensitivity analysis of lake water level response to changes in climate and river regimes. Limnologica-Ecology and Management of Inland Waters. 51, 118-130.

Haghighi, A. T. and Kløve, B., 2013. Development of a general river regime index (RRI) for intra-annual flow variation based on the unit river concept and flow variation end-points. Journal of Hydrology. 503, 169-177. 
Haghighi, A. T., Menberu, M. W., Aminnezhad, M., Marttila, H., Kløve, B., 2016. Can lake sensitivity to desiccation be predicted from lake geometry? Journal of Hydrology. 539, 599-610.

Hamzekhani, F. G., Saghafian, B., Araghinejad, S., 2016. Environmental management in Urmia Lake: thresholds approach. International Journal of Water Resources Development. 32, 77-88.

Hassanzadeh, E., Zarghami, M., Hassanzadeh, Y., 2012. Determining the main factors in declining the Urmia Lake level by using system dynamics modeling. Water Resources Management. 26, 129-145.

Jalili, S., Hamidi, S. A., Namdar Ghanbari, R., 2016. Climate variability and anthropogenic effects on Lake Urmia water level fluctuations, northwestern Iran. Hydrological Sciences Journal. 61, 1759-1769.

Jarsjö, J., Asokan, S. M., Prieto, C., Bring, A., Destouni, G., 2012. Hydrological responses to climate change conditioned by historic alterations of land-use and water-use. Hydrology and Earth System Sciences. 16, 13351347.

Jellison, R., Williams, W.D., Timms, B., Alcocer, J., Aladin, N.V., 009. Salt lakes: values, threats and future, in: Polunin, N. V. C. (Ed.), Aquatic Ecosystems: Trends and Global Prospects. Cambridge University Press, Cambridge, pp. 94-110.

JICA, 2016. Japan International Cooperation Agency. Data Collection Survey on Hydrological Cycle of Lake Urmia Basin in the Islamic Republic of Iran. FINAL REPORT. GE JR 16-037, .

Keddy, P. A., Fraser, L. H., Solomeshch, A. I., Junk, W. J., Campbell, D. R., Arroyo, M. T., Alho, C. J., 2009. Wet and wonderful: the world's largest wetlands are conservation priorities. Bioscience. 59, 39-51.

Krysanova, V. and White, M., 2015. Advances in water resources assessment with SWAT — an overview. Hydrological Sciences Journal. 60, 771-783.

Li, Y., Chang, J., Wang, Y., Jin, W., Guo, A., 2016. Spatiotemporal Impacts of Climate, Land Cover Change and Direct Human Activities on Runoff Variations in the Wei River Basin, China. Water. 8, 220.

López-Moreno, J. I., Beguería, S., García-Ruiz, J. M., 2004. The management of a large Mediterranean reservoir: storage regimens of the Yesa Reservoir, Upper Aragon River Basin, central Spanish Pyrenees. Environmental Management. 34, 508-515.

Mango, L. M., Melesse, A. M., McClain, M. E., Gann, D., Setegn, S. G., 2011. Land use and climate change impacts on the hydrology of the upper Mara River Basin, Kenya: results of a modeling study to support better resource management. Hydrol. Earth Syst. Sci. 15, 2245-2258.

Masih, I., Uhlenbrook, S., Maskey, S., Smakhtin, V., 2011. Streamflow trends and climate linkages in the Zagros Mountains, Iran. Climatic Change. 104, 317-338.

Milly, P. C., Dunne, K. A., Vecchia, A. V., 2005. Global pattern of trends in streamflow and water availability in a changing climate. Nature. 438, 347-350.

Moore, J. N., 2016. Recent desiccation of Western Great Basin Saline Lakes: Lessons from Lake Abert, Oregon, USA. Science of the Total Environment. 554, 142-154.

OWWMP, 2011a. Iran Ministry of Energy's Office for Water and Wastewater Macro-Planning. Iran's comprehensive water resources plan. Agricultural Water use (Lake Urmia Watershed) Report. 2385070-4420, .

OWWMP, 2011b. Iran Ministry of Energy's Office for Water and Wastewater Macro-Planning. Iran's comprehensive water resources plan. Meteorological Report. 2385070-4420, . 
OWWMP, 2011c. Iran Ministry of Energy's Office for Water and Wastewater Macro-Planning. Iran's comprehensive water resources plan. Groundwater Studies (Lake Urmia Watershed) Report.

Peñas, F., Barquín, J., Álvarez, C., 2016. Assessing hydrologic alteration: Evaluation of different alternatives according to data availability. Ecological Indicators. 60, 470-482.

Saghafian, B. and Hamzekhani, F. G., 2015. Hydrological drought early warning based on rainfall threshold. Natural Hazards. 79, 815-832.

Shibuo, Y., Jarsjö, J., Destouni, G., 2007. Hydrological responses to climate change and irrigation in the Aral Sea drainage basin. Geophysical Research Letters. 34, .

Stefanidis, K., Panagopoulos, Y., Psomas, A., Mimikou, M., 2016. Assessment of the natural flow regime in a Mediterranean river impacted from irrigated agriculture. Science of the Total Environment. 573, 1492-1502.

Talebi, T., Ramezani, E., Djamali, M., Lahijani, H. A. K., Naqinezhad, A., Alizadeh, K., Andrieu-Ponel, V., 2015. The Late-Holocene climate change, vegetation dynamics, lake-level changes and anthropogenic impacts in the Lake Urmia region, NW Iran. Quaternary International. 408, 40-51.

Torabi Haghighi, A., Marttila, H., Kløve, B., 2014. Development of a new index to assess river regime impacts after dam construction. Global and Planetary Change. 122, 186-196.

Tourian, M., Elmi, O., Chen, Q., Devaraju, B., Roohi, S., Sneeuw, N., 2015. A spaceborne multisensor approach to monitor the desiccation of Lake Urmia in Iran. Remote Sensing of Environment. 156, 349-360.

Vicente-Serrano, S. M., Zabalza-Martínez, J., Borràs, G., López-Moreno, J. I., Pla, E., Pascual, D., Savé, R., Biel, C., Funes, I., Martín-Hernández, N., 2017. Effect of reservoirs on streamflow and river regimes in a heavily regulated river basin of Northeast Spain. Catena. 149, 727-741.

Wang, R., Kalin, L., Kuang, W., Tian, H., 2014. Individual and combined effects of land use/cover and climate change on Wolf Bay watershed streamflow in southern Alabama. Hydrological Processes. 28, 5530-5546.

Wang, Y., Rhoads, B. L., Wang, D., 2016. Assessment of the flow regime alterations in the middle reach of the Yangtze River associated with dam construction: potential ecological implications. Hydrological Processes. 30 , 3949-3966.

Williams, W. D., 2002. Environmental threats to salt lakes and the likely status of inland saline ecosystems in 2025. Environmental Conservation. 29, 154-167.

Wu, Y., Liu, S., Abdul-Aziz, O. I., 2012. Hydrological effects of the increased CO2 and climate change in the Upper Mississippi River Basin using a modified SWAT. Climatic Change. 110, 977-1003.

Wurtsbaugh, W., 2014. Management of the Great Salt Lake Ecosystem: Water, Economic Values and Competing Interests.Utah State University Watershed Science Faculty Publication 594.

Yang, C., Lin, Z., Yu, Z., Hao, Z., Liu, S., 2010. Analysis and simulation of human activity impact on streamflow in the Huaihe River basin with a large-scale hydrologic model. Journal of Hydrometeorology. 11, 810-821.

Zamani, R., Mirabbasi, R., Abdollahi, S., Jhajharia, D., 2016. Streamflow trend analysis by considering autocorrelation structure, long-term persistence, and Hurst coefficient in a semi-arid region of Iran. Theoretical and Applied Climatology. 1-13.

Zhan, C., Niu, C., Song, X., Xu, C., 2013. The impacts of climate variability and human activities on streamflow in Bai River basin, northern China. Hydrology Research. 44, 875-885. 
Zhang, L., Nan, Z., Xu, Y., Li, S., 2016. Hydrological impacts of land use change and climate variability in the headwater region of the Heihe River Basin, Northwest China. PloS ONE. 11, e0158394. 